\title{
Sorgulamaya dayalı öğretiminin Ay'ın evreleri konusunda öğrencilerin kavramsal anlamalarına etkisi
}

\author{
Ayberk BOSTAN SARIOĞLAN ${ }^{*}$, , Melike Gülsüm BAYIRLI ${ }^{2}$ \\ ${ }^{1}$ Balıkesir Üniversitesi, Necatibey Eğitim Fakültesi, Matematik ve Fen Bilimleri Eğitimi, Balıkesir \\ ${ }^{2}$ Ballkesir Üniversitesi, Fen Bilimleri Enstitüsü, Matematik ve Fen Bilimleri Eğitimi, Balıkesir \\ Gelis Tarihi (Recived Date): 21.08 .2017 \\ Kabul Tarihi (Accepted Date): 07.11.2017
}

\begin{abstract}
Özet
Fen derslerinde son yıllarda sorgulamaya dayalı eğitim ve ögretim faaliyetleri ön planda tutulmaktadır. Bu nedenle de sorgulamaya dayalı ögretim, öğrencilerin derse karşı verimliliğini ve derse olan motivasyonunu arttırmak amacı ile araştırmacılar tarafindan çalı̧̧ma konusu olarak tercih edilmektedir. Bu çalışmada sorgulamaya dayal öğretimin ortaokul 6.sınıf "Ay'ın Evreleri” konusunda öğrencilerin başarısına etkisinin araştırılması amaçlanmıştır. Çalı̧̧ma grubu olarak 6.sinıfta öğrenim görmekte olan yirmi dört ortaokul öğrencisi belirlenmiştir. Veri toplama aracı olarak yedi açık uçlu sorudan oluşan bir kavram testi öğretim öncesi ve öğretim sonrası öğrencilere uygulanmıştır. Sonuç olarak, sorgulamaya dayalı öğretim modelinin Ay'ın evreleri kavramı ile ilgili öğrencilerin bilimsel cevap vermelerinde etkili olduğu belirlenmiştir.
\end{abstract}

Anahtar Kelimeler: Sorgulamaya dayalı ögretim, Ay’ın evreleri, ortaokul öğrencileri

\section{Effects of inquiry based instruction on students' achievement regarding to the phases of moon}

\begin{abstract}
In science courses, research and inquiry education and training activities have been held in the foreground in recent years. For this reason, inquiry-based teaching is preferred by the researchers as a study topic in order to increase the students' productivity against the lesson and the motivation of the lesson. In this study, it was aimed to investigate the effect of inquiry-based teaching on the success of the students in the 6th grade "Moon's Stages" of secondary school. Twenty-four middle school students who were studying at the 6th grade were identified as the study group. A concept test consisting of seven open-ended questions was used as pre-instruction and post-instructional students as a data collection tool. As a result, it has been determined that inquiry based teaching model is effective in providing students with scientific answer about the concept of matrices.
\end{abstract}

Keywords: Inquiry instruction, phases of the moon, middle school students

\footnotetext{
* Ayberk BOSTAN SARIOĞLAN, abostan@balikesir.edu.tr, http://orcid.org/0000-0002-2320-9427

Melike Gülsüm BAYIRLI, melikebayirli@gmail.com, https://orcid.org/0000-0002-6813-0683
} 


\section{Giriş}

Fen Bilimleri dersi programlarının, bilimsel bilgilerin değişmesi, gelişmesi veya yenilenmesi sebebi ile düzenlenmesi veya geliştirilmesine ihtiyaç duyulmaktadır. MEB program geliştirmede hayat boyu öğrenmeyi temel referans almıştır. Bu amaçla öğrencilerin bilimsel düşünce, araştırma-sorgulama, eleştirisel yaklaşımlar ve problem çözme becerilerini kazandırma faaliyetlerini ön planda tutarak 2013 yılında fen bilimleri dersi öğretim programı uygulanmaya başlamıştır. $\mathrm{Bu}$ amaçla Fen Bilimleri Dersi Öğretim Programında araştırma-sorgulamaya dayalı öğrenme yaklaşımı temel alınmıştır [1]. Araştırma ve sorgulamaya dayalı öğrenme, bir süreçtir. Bu süreç öğrencilerin etkinliklerde etkin olarak yer alarak elde ettikleri bilgileri anlamlı bir şekilde yapılandırdığı bir süreç olarak tanımlanmaktadır [2].

Sorgulamaya dayalı öğretim, öğrencilerin bilinmeyen olguları merak ile araştırarak açıklayacakları ve bunu açıklamak için yapacakları çalışmaları içermektedir [3]. Sorgulamaya dayalı öğretim, öğrencilere yaşamı boyunca karşılaşacağı soyut ve somut problemleri çözme becerisi kazandırır. Ayrıca öğrencilerde soru sorma, eleştirel düşünme mantığını geliştirdiğinden, öğrencilerin tüm yaşamı boyunca ihtiyaç duyacağ yetenekleri geliştirmesine imkân sağlar. Bu öğretim, öğrencilerin derslere dahil olarak bilimsel bilginin ortaya çıkması için hazırlanan yöntemle öğrencilere deneyimler kazandırılabilmektedir [4]. Birçok çalışmada sorgulamaya dayalı öğrenme yöntemi kullanılarak araştırmalar yürütülmektedir. $\mathrm{Bu}$ araştırmaların çalışma konuları birbirinden farklıdır. Yapılan bu çalışmalara çeşitli örnekler aşağıda verilmektedir.

Bir araştırmada, araştırma sorgulamanın 60-72 aylık çocukların bilim öğrenmelerine etkisi incelenmektedir [5]. Çalışma sonucunda çalışma grubundaki bireylerde öğretimin bilimin öğrenilmesinde etkili olduğu tespit edilmiştir. Bir başka çalışmada; sorgulamanın ön planda olduğu öğretimin sınıf öğretmeni adaylarının fen öğretimine karşı olumlu tutumlar geliştirmelerinde etkili olduğunu tespit edilmiştir [6]. Yapılan bir araştırmada, araştırma sorgulamaya dayalı etkinlikler sonucunda öğrencilerdeki sorgulama becerilerinde, deney grubunun kontrol grubuna göre son test puanının yüksek olduğunu gözlemlenmiştir [7]. Bir diğer çalışmada ise, araştırma sorgulamaya dayalı fen öğretimi sonucunda öğrencilerin fen bilimlerine yönelik tutumlarında ve bilimsel süreç becerilerinde anlamlı bir değişikliğin olduğunu tespit edilmiştir [8].
Sorgulamaya dayalı öğretimin uygulanması için hazırlanan planlar çeşitlilik göstermektedir. $\mathrm{Bu}$ planlarda öğrenme halkası, $5 \mathrm{E}$ veya $7 \mathrm{E}$ kullanılabilmektedir. Bu yöntemlerin kullanıldığ1 birçok çalışma bulunmaktadır. Bir çalışmada elektrik konusu öğretiminde 5E planı kullanılmaktadır. 5E planının öğrencilerin tutumuna etkisine bakılmaktadır. Bu çalışmanın sonucunda deney grubunda kontrol grubuna göre anlamlı bir farklılık bulunmuştur [9]. Bir çalışmada da kavramsal değişim etkinlikleri ile zenginleştirilmiş 5E planı kullanılmaktadır [10]. $\mathrm{Bu}$ plan öğrencilerin bazı astronomi konuları ile ilgili kavramsal değişime olan etkisini araştırmaktadır. Araştırma yöntemi olarak; yarı deneysel yöntem kullanılmıştır. Bu çalışmanın sonucunda kavramsal anlama testinin son test puanları arasında deney grubunun daha önde olduğu tespit edilmektedir. Bir diğer çalışmada 5E ögretim modeli kuvvet ve hareket konusunun ögretiminde kullanılmaktadır. Deney ve kontrol grubundan oluşan bu çalışmanın sonucunda deney grubunun kontrol grubuna göre daha başarılı olduğu tespit edilmektedir[11]. Yapılan bir çalışmada sorgulamaya dayalı etkinliklerin içerdiği 5E planının 5.sınıf öğrencilerinin çevre ile ilgili tutum ve davranışlarına etkisi incelenmiştir. Araştırmada yapılan uygulamalar sonucunda öğrencilerde tutum ve davranışlarındaki değişikliğin anlamlı olduğu tespit edilmiştir [12]. Bir diğer çalışmada, elektrik konusunda 7E planı kullanılmaktadır [13]. Planın amacı öğrencilerin basit elektrik devresi ile ilgili kavramsal değişimin ve bu değişimin kalıcılığının incelenmesidir. $\mathrm{Bu}$ çalışmanın sonucunda 7E planının uygulandığı grupta kavram yanılgılarının giderilmesinde etkili olduğu tespit edilmiştir.

Ay, Dünyamızın doğal uydusu olmasından dolayı araştırılması muhtemel konulardan biridir. Birçok araştırmada da Ay ve evreleri çalışma konusu olmaktadır. Ay'ın evreleri ile ilgili öğretim sürecinde 5E planı uygulanmıştır [14]. Bu çalışma sonucunda bazı durumlarda öğrencilerin gözlem yapmayarak eski fikirlerine devam ettikleri gözlemlenmektedir. Diğer bir çalışmada ise Ay'ın evreleri konusundaki kavram yanılgılarının tespit edilmesi amaçlanmıştır [15]. Çalışma sonucunda işbirlikli gruptaki öğrencilerdeki kavram yanılgılarının giderildiği tespit edilmiştir. Ayrıca geleneksel gruba göre işbirlikli gruptaki öğrencilerin bilimsel kavram düzeyine geçmeleri çok daha kolay olduğu gözlemlenmiştir. Bir diğer araştırmada Güneş, Dünya ve Ay’ın zihinsel modelleri çalışma konusu seçilmiştir [16]. Bu çalışmanın sonucunda öğrencilerin modelleri kendilerine göre yorumlamakta oldukları tespit edilmiştir. Bir başka araştırmada ise Dünyanın şekli ve yerçekimi kavramlarına ilişkin zihinsel modellerini incelenmiştir [17]. Çalışma 
sonucunda öğrencilerin sınıf düzeyi büyüdükçe zihinsel modellerinde bir miktar gelişmenin olduğu fakat her iki grupta da farklı zihinsel modeller ortaya koydukları tespit edilmiştir. Ay'ın evreleri konusuyla ilgili kavramsal değişimin incelendiği çalışmalar da bulunmaktadır [18, 19]. Bir başka çalışmada ise anaokulu öğrencilerinin Ay evreleri ile ilgili fikirlerini belirlemeyi amaçlamıştır. Çocuklar ile yapılan mülakatlar, ögrrencilerin bu kavramları ailelerinden, gündelik deneyimlerinden ve gözlemlerinden aldığını göstermektedir [20]. Buradan çıkaracağımız sonuç araştırmasorgulamaya dayalı öğretim ve Ay'ın evreleri konuları birçok çalışmada araştırma konusu olmuştur ve bu araştırmalar gelişen teknoloji ve araştırmalarla devam edecektir. Bu araştırma da ise bu çalışmalardan farklı olarak Ay'ın evreleri konusuyla araştırma-sorgulamaya dayalı öğretim harmanlanmaktadır. Çalışmanın sonucunda 6 . sınıf öğrencilerin Ay'ın evreleri konusunda araştırma sorgulamanın etkililiği ve öğretim sonucunda öğrencilerin kavramsal anlamalarına etkisi incelenmektedir.

\section{Yöntem}

\section{1. Araşturma modeli}

$\mathrm{Bu}$ çalışma, araştırma türlerinden zayıf deneysel desen ön-test son-test tek grup içeren bir çalışmadır. Zayıf deneysel desenler rastgele seçimin olmadığı tek bir çalışma grubunu içeren çalışmaları içerir [21]. $\mathrm{Bu}$ çalışmada rastgele seçim bulunmadığından ve çalışma tek grup içermesinden bu araştırma yöntemi belirlenmiştir.

\section{2. Calışma grubu}

Araştırmadaki çalışma grubunu Manisa'daki bir devlet okulundaki $24 \quad 6$. sinıf öğrencisi oluşturmaktadır.

\section{3. Veri toplama aracı}

Öğretim öncesi ve öğretim sonrası öğrencilere yöneltilmek için hazırlanan sorular önceden yapılmış bir çalışmadan yararlanılmıştır [14]. Bu sorular Ay'ın evrelerinin oluşum sebeplerini ve sıralamasını ayrıca Ay'ın evrelerini Dünya, Güneş ve Ay'ın konularına göre çizmeleri ve bunun tam tersi olduğu durum yani; Dünya, Güneş ve Ay’ın konumuna göre Ay'ın hangi evrede olduğunu belirttikleri soruları içermektedir. $\mathrm{Bu}$ amaçla öğrencilere 7 açık uçlu soru sorulmuştur. Öğrenciler öğretim öncesi ve sonrası bu soruları cevaplamışlardır.

\section{4. Verilerin analizi}

Kavram testinde yer alan soruların analizinde betimsel analiz yöntemi kullanılmış ve frekans hesabı yapılmıştır. Bu soruların analizi için dört kategoriden oluşan bir rubrik kullanılmıştır. $\mathrm{Bu}$ kategoriler "bilimsel olarak kabul edilebilir yanitlar", "bilimsel olarak kabul edilemez yanitlar", "kodlanamaz" ve "cevap yok" şeklindedir. Bilimsel olarak kabul edilen yanıtlar ikiye ayrılmıştır. Cevabı ve açıklaması doğru olan cevaplar "tam doğru" kategorisine, cevabı doğru fakat yeterli açıklama yoksa veya açıklama yapılmamışsa "kısmi doğru" kategorisine yazılmıştır. Yanlış cevaplar "bilimsel olarak kabul edilemez" kategorisine, alakalı olmayan cevaplar "kodlanamaz" kategorisine ve soruya cevap vermeyenler "cevap yok" kategorisine alınmışlardır. Her bir kategoride yer alan öğrenci cevaplarının frekansları ve yüzdelik değerleri hesaplanmıştır.

\section{5. Öğretim süreci}

Öğretim süreci 4 ders saati olarak belirlenmiş ve uygulanmıştır. Araştırma-sorgulamaya dayalı ders planında öğrenme halkası modeli kullanılmıştır. Keşfetme aşaması için öğrencilerin dikkatlerini çekici ve sorgulamalarını sağlayacağı bir video izlettirilmiştir. Videodaki “Ay'ın birkaç hafta öncesine göre neden farklı görüldüğü, bu farklılığın neden kaynaklanmış olabileceğii” sorusu öğrencilere sorulmuştur. Videoda ki soruyla sorgulama dersi başlatılmıştır. Daha sonra öğrencilere Ay takvimi gösterilerek Ay'ın evrelerinin kaç tane olabileceği ve bazı Ay resimlerinde Ay'ın görülüp görülmediği sorusu hakkında tahminde bulunmaları istenmiştir. Öğretmen bu konuyla ilgili açıklamalarda bulunmuştur.

Kavram öğretimi aşamasında, öğrenciler ile Ay'ın evrelerini modelleyebilecekleri bir etkinlik yapılmıştır. Etkinlik sonrası öğrenciler gruplara ayrılmıştır. Gruplara tartışmaları ve not almaları için 2 sorudan oluşan çalışma yaprağı dağıtılmıştır. Öğretmen öğrencilere Ay'ın evrelerinin bir sırasının olup olmadığını sormuş ve sınıfça soru cevapları tartışılmıştır. Öğretmen Ay'ın evrelerinin 4 tane olduğunu ve evrelerin neler oldukları hakkında bilgiler vermiştir.

Kavram uygulaması aşamasında, Ay’ın konumuna göre hangi evrede olabileceğiyle ilgili etkinlik yapılmıştır. Etkinlik sonunda öğrencilerden dağıtılan malzemeler kullanılarak Ay'ın evrelerinin modelini oluşturmaları istenmiş ve öğretim sonlandırılmıştır.

\section{Bulgular ve yorumlar}

$\mathrm{Bu}$ bölümde öğretim öncesi ve sonrası uygulanan kavram testinde yer alan soruların analizinde elde edilen bulgulara yer verilmektedir.

Birinci soruda, öğrencilerden Ay'ın evrelerinin oluşum sebeplerini açıklamaları istenmektedir. 
Cevaplar incelendiğinde “Ay'ın Dünya'nın etrafında dönmesi” cevabı tam doğru cevaplarda, “Ay'ın hareket etmesi” kısmi doğru cevaplarda, “Ay'ın Güneş’ten aldığı 1şınlarla Dünya'ya yansıyıp yansımadığını görmek için” bilimsel olarak kabul edilemez cevaplarda, “Dünya'nın sabah olduğunu anlamak" kodlanamaz cevaplarda, cevap vermeyenler ise cevap yok kategorisinde yer almaktadır. Birinci sorunun analizinden elde edilen bulgular Tablo 1'de yer almaktadır.

Tablo 1. Birinci soruya ait öğrenci yanıtlarının dağılımı

\begin{tabular}{|c|c|c|c|c|}
\hline \multirow{2}{*}{ Cevap Kategorileri } & \multicolumn{2}{|c|}{ Öğretim öncesi } & \multicolumn{2}{|c|}{ Öğretim sonrası } \\
\hline & $\mathrm{n}$ & $\mathrm{f}(\%)$ & $\mathrm{n}$ & $\mathrm{f}(\%)$ \\
\hline Bilimsel Olarak Kabul & 1 & $\% 4.16$ & 17 & $\% 70.84$ \\
\hline$K I S M I \dot{I} D O \breve{G} R U$ & 8 & $\% 33.33$ & 3 & $\% 12.5$ \\
\hline Bilimsel Olarak Kabul Edilemez Cevaplar & 8 & $\% 33.33$ & 1 & $\% 4.16$ \\
\hline Kodlanamaz & 3 & $\% 12.50$ & 1 & $\% 4.16$ \\
\hline Cevap Yok & 4 & $\% 16.67$ & 2 & $\% 8.34$ \\
\hline
\end{tabular}

Tablo 2. İkinci soruya ait öğrenci yanıtlarının dağılımı

\begin{tabular}{|c|c|c|c|c|}
\hline \multirow{2}{*}{ Cevap Kategorileri } & \multicolumn{2}{|c|}{ Öğretim Öncesi } & \multicolumn{2}{|c|}{ Öğretim Sonrası } \\
\hline & $\mathrm{n}$ & $\mathrm{f}(\%)$ & $\mathrm{n}$ & $\mathrm{f}(\%)$ \\
\hline \multirow{2}{*}{$\begin{array}{l}\text { Bilimsel Olarak } \\
\text { Kabul Edilebilir Cevaplar }\end{array}$} & - & - & 1 & $\% 4.16$ \\
\hline & 7 & $\% 29.17$ & 10 & $\% 41.67$ \\
\hline \multirow{3}{*}{$\begin{array}{l}\text { Bilimsel Olarak Kabul Edilemez Cevaplar } \\
\text { Kodlanamaz } \\
\text { Cevap Yok }\end{array}$} & 2 & $\% 8.33$ & - & - \\
\hline & 15 & $\% 62.50$ & 13 & $\% 54.17$ \\
\hline & - & - & - & - \\
\hline
\end{tabular}

Tablo 3. Üçüncü soruya ait öğrenci yanıtlarının dağılımı

\begin{tabular}{|c|c|c|c|c|}
\hline \multirow{2}{*}{ Cevap Kategorileri } & \multicolumn{2}{|c|}{ Öğretim Öncesi } & \multicolumn{2}{|c|}{ Öğretim Sonrası } \\
\hline & $\mathrm{n}$ & $\mathrm{f}(\%)$ & $\mathrm{n}$ & $\mathrm{f}(\%)$ \\
\hline Bilimsel Olarak Kabul & - & - & 2 & $\% 8.34$ \\
\hline Edilebilir Cevaplar & 12 & $\% 50.00$ & 9 & $\% 37.50$ \\
\hline Bilimsel Olarak Kabul Edilemez Cevaplar & 10 & $\% 41.67$ & 12 & $\% 50.00$ \\
\hline Kodlanamaz & 1 & $\% 4.16$ & 1 & $\% 4.16$ \\
\hline Cevap Yok & 1 & $\% 4.16$ & - & - \\
\hline
\end{tabular}

Tablo 4. Dördüncü soruya ait öğrenci yanıtlarının dağılımı

\begin{tabular}{llllll}
\hline & \multirow{2}{*}{ Cevap Kategorileri } & \multicolumn{2}{c}{ Öğretim Öncesi } & \multicolumn{3}{c}{ Öğretim Sonrasi } \\
& & $\mathrm{n}$ & $\mathrm{f}(\%)$ & $\mathrm{n}$ & $\mathrm{f}(\%)$ \\
\hline Bilimsel Olarak Kabul & TAM DOĞRU & - & - & 10 & $\% 41.67$ \\
Edilebilir Cevaplar & KISMİ DOĞRU & - & - & 9 & $\% 37.50$ \\
Bilimsel Olarak Kabul Edilemez Cevaplar & 23 & $\% 95.84$ & 5 & $\% 20.83$ \\
Kodlanamaz & & 1 & $\% 4.16$ & - & - \\
Cevap Yok & - & - & - & - \\
\hline
\end{tabular}

Tablo 5. Beşinci soruya ait öğrenci yanıtlarının dağılımı

\begin{tabular}{|c|c|c|c|c|}
\hline \multirow{2}{*}{ Cevap Kategorileri } & \multicolumn{2}{|c|}{ Öğretim öncesi } & \multicolumn{2}{|c|}{ Öğretim sonrası } \\
\hline & $\mathrm{n}$ & $\mathrm{f}(\%)$ & $\mathrm{n}$ & $\mathrm{f}(\%)$ \\
\hline Bilimsel Olarak Kabul & 1 & $\% 4.16$ & 3 & $\% 12.50$ \\
\hline$K I S M \dot{I} D O \breve{G} R U$ & 4 & $\% 16.67$ & 14 & $\% 58.33$ \\
\hline Bilimsel Olarak Kabul Edilemez Cevaplar & 19 & $\% 79.17$ & 7 & $\% 29.17$ \\
\hline Kodlanamaz & - & - & - & - \\
\hline Cevap Yok & - & - & - & - \\
\hline
\end{tabular}

Tablo 1 incelendiğinde, öğretim öncesi öğrencilerin \%37.49'nun bilimsel olarak kabul edilebilir yanıt verdiği ve son testte bu oranın $\% 83.34$ 'e yükseldiği görülmektedir. Ayrıca bilimsel olarak kabul edilemez cevap kategorisinde yer alan cevaplarda azalma olduğu gözlemlenmektedir. Öğretim öncesi öğrencilerin verdiği cevapların \%33.33'nün bu kategoride yer alırken, öğretim sonrası cevapların yalnızca \%4.16'sı bu kategoride yer almıştır. Öğretim sonras1 kodlanamaz cevapların \%12.5'dan \% 4.16'ya düştüğü gözlemlenmektedir. Cevap yok 
kategorisinde ise öğretim öncesinde öğrencilerin \%16.67 yer alırken iken bu sayı öğretim sonrasında \%8.34'e düşmüştür. $\mathrm{Bu}$ soruda sorgulamaya dayalı öğretimin öğrencilerde Ay'ın evrelerinin oluşum sebepleri ile ilgili fikirlerinde etkili olduğu tespit edilmiştir.

Íkinci soruda, Öğrencilerden Ay’ın kaç türlü hareketi olduğu ve bunların neler olduğunu açıklamaları istenmektedir. Cevaplar incelendiğinde; "Kendi etrafında, Dünya etrafında ve Dünya ile birlikte Güneş etrafında dönüşü" tam doğru cevabında, "Dünya etrafında ve Güneş etrafında dönmesi” kısmi doğru cevabında, “2 türlü hareketi vardır. Biri kendi etrafında dönme ve biride dönerken ilerleme" bilimsel olarak kabul edilemez cevaplarda, "yarım ay, hilal, dolunay, yeni ay, ilk ay, son ay" kodlanamaz cevaplarda, cevap vermeyenlerde cevap yokta yer almaktadır. İkinci sorunun analizinden elde edilen bulgular Tablo 2'de yer almaktadır.

Tablo 2 incelendiğinde, öğrencilerin bilimsel olarak kabul edilebilir cevapların öğretim öncesi \%29.17 olduğu, öğretim sonrasında ise bu cevapların \%45.83'e yükseldiği gözlemlenmiştir. Bilimsel olarak kabul edilemez cevaplar kategorisinde öğretim öncesi 2 öğrencinin verdiği cevaplar yer alırken öğretim sonrasında bu cevap kategorisinde kimse bulunmamaktadır. Kodlanamaz cevaplar öğretim öncesinde \%62.50 iken öğretim sonrasında bu sayı \%54.17 olarak karşımıza çıkmaktadır. Bunun sebebi; öğrencilere Ay'ın hareketleri sorulduğunda öğrencilerin bu soruyu Ay'ın evreleri ile karıştırmasından ve bu yönde cevap vermelerinden kaynaklanmaktadır. Cevap yok kategorisinde öğretim öncesi ve sonrasında kimse bulunmamaktadır.

Ücüncü soruda, öğrencilerden Ay'ın evrelerini oluşum sıralarına göre çizmeleri istenmektedir. Cevaplar incelendiğinde, "çizimlerle yeni ay, ilk dördün, dolunay, son dördün" tam doğru cevaplarda, çizimin doğru sıranın yanlış olduğu cevaplar kısmi doğru cevaplarda, "ilk dördün, hilal, yarım ay, dolunay, son dördün, yeni ay" bilimsel olarak kabul edilemez cevaplarda, Güneş, Dünya ve Ay'ın çizimlerinin olduğu cevaplar kodlanamaz cevaplarda, cevap vermeyenler ise cevap yokta yer almaktadır. Üçüncü sorunun analizinden elde edilen bulgular Tablo 3'de yer almaktadır.

Tablo 3 incelendiğinde; bilimsel olarak kabul edilebilir cevapların oranı öğretim öncesinde $\% 50.00$ bulunurken bu oran öğretim sonrasında \%45.84'e düşmektedir. Bilimsel olarak kabul edilemez cevaplar öğretim öncesinde \%41.67'den, öğretim sonrasında bu sayı \%50.00'ye yükselmektedir. Kodlanamaz cevap kategorisinde öğretim öncesi ve sonrasında aynı sayıda öğrenci bulunmaktadır. Cevap yok kategorisinde öğretim öncesi 1 ögrrencinin verdiği cevap yer alırken, ögretim sonrasında cevap vermeyen öğrenci kalmamıştır. $\mathrm{Bu}$ soruda öğrencilerin öğretim sonrası Ay'ın evrelerini sırası ile çizmede öğretim öncesine oranla başarılı olamamıştır.

Dördüncü soruda, Öğrencilerden Güneş, Dünya ve Ay'ın konumlarını çizerek Dolunay'ın nasıl oluştuğunu göstermeleri istenmektedir. Cevaplar incelendiğinde büyüklüklerin de dikkate alınarak Güneş-Dünya-Ay sırası çizimi tam doğru cevaplarda, büyüklüklerin dikkate alınarak GüneşDünya-Ay çizen fakat Dolunay yerine son dördün şeklini çizenler kısmi doğru cevaplarda, sıralamanın yanlış olduğu çizimler bilimsel olarak kabul edilemez cevaplarda, büyüklüklerin yanlış olduğu çizimler kodlanamaz cevaplarda, cevap vermeyenler cevap yokta yer almaktadir. Dördüncü sorunun analizinden elde edilen bulgular Tablo 4'de yer almaktadır.

Tablo 4 incelendiğinde; bilimsel olarak kabul edilebilir cevaplar kategorisinde ön testte cevap veren kimse yoktur. Fakat öğretim sonrasında bilimsel cevap oranı \%79.17'ye çıkmıştır. Bilimsel olarak kabul edilemez cevaplar incelendiğinde öğretim öncesinde öğrencilerin verdiği cevapların \%95.84'ü bu kategoride yer alırken, öğretim sonrasında bu oran anlamlı bir azalma göstererek \%20.83'e düşmektedir. Kodlanamaz cevabında öğretim öncesinde 1 öğrencinin verdiği cevap yer alırken, öğretim sonrasinda bu cevap kategorisinde yer alan cevap bulunmamaktadır. Cevap yok kategorisinde öğretim öncesi ve sonrasında kimse bulunmamaktadır.

Beşinci soruda, öğrencilerden Güneş, Dünya ve Ay'ın konumlarını çizerek Yeniay'ın nasıl oluştuğunu göstermeleri istenmektedir. Cevaplar incelendiğinde; büyüklüklerin dikkate alınarak Güneş-Ay-Dünya sırası çizimi tam doğru cevaplarda, büyüklüklerin ve siralamanın doğru, Ay'ın son dördün şeklindeki çizimler kısmi doğru cevaplarda, Güneş-Dünya-Ay sıralaması bilimsel olarak kabul edilemez cevaplarda yer almaktadir. Beşinci sorunun analizinden elde edilen bulgular Tablo 5'de yer almaktadir.

Tablo 5 incelendiğinde; öğrencilerin bilimsel olarak kabul edilebilir cevapların öğretim öncesinde \%20.83 iken ögretim sonrasında bu oranın \%70.83'e yükseldiği gözlemlenmektedir. $\mathrm{Bu}$ soruda öğretim öncesinde öğrencilerin verdiği cevapların bilimsel olarak kabul edilemez cevap kategorisinde yer alma oranı \%79.17 iken, ögretim sonrasında bu oranın \%29.17'ye gerilediği gözlemlenmektedir. Bu soruda öğretim öncesi ve 
sonrasinda da kodlanamaz ve cevap yok kategorisinde yer alan öğrenci cevab1 bulunmamaktadır.

Altıncı soruda, öğrencilere Şekil 1'deki gibi Güneş, Dünya ve Ay'ın konumları verilerek Ay'ın hangi evrede olabileceği sorusu sorulup, çizerek açıklamaları istenmiştir. Cevaplar incelendiğinde; ilk dördün çizip ve açıklayanlar tam doğru cevaplarda, çizen fakat açıklamada bulunmayanlar kısmi doğru cevaplarda, "yeni ay, dolunay" gibi cevaplar bilimsel olarak kabul edilemez cevaplarda, "adını bilmiyorum" kodlanamaz cevaplarda, cevap vermeyenler cevap yokta yer almaktadır. Altıncı sorunun analizinden elde edilen bulgular Tablo 6'da yer almaktadir.

Tablo 6 incelendiğinde; bilimsel olarak kabul edilebilir cevaplarda öğretim öncesinde kimse bulunmazken, öğretim sonrasında bu oranın \%54.17'ye yükseldiği gözlemlenmiştir. Bilimsel olarak kabul edilemez cevapların öğretim öncesinde sınıfın \%83.34'ünü oluştururken bu oran öğretim sonrasında \%45.83'e gerilediği gözlemlenmektedir. Kodlanamaz cevaplarda ögretim öncesinde 1 öğrencinin verdiği cevap yer alırken ögrretim sonrasında bu cevap kategorisinde yer alan cevap bulunmamaktadir. Cevap yok kategorisinde öğretim öncesinde sinıfın \%12.5'i bulunurken, ögrretim sonrasında bu kategoride kimsenin bulunmadığı gözlemlenmektedir.
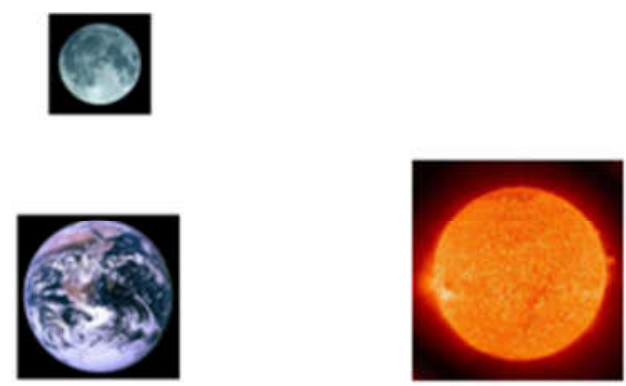

Şekil 1. Altıncı soruya ait Dünya, Güneş ve Ay’ın konumları

Tablo 6. Altıncı soruya ait öğrenci yanıtlarının dağılımı

\begin{tabular}{|c|c|c|c|c|}
\hline \multirow{2}{*}{ Cevap Kategorileri } & \multicolumn{2}{|c|}{ Öğretim Öncesi } & \multicolumn{2}{|c|}{ Öğretim Sonrası } \\
\hline & $\mathrm{n}$ & $\mathrm{f}(\%)$ & $\mathrm{n}$ & $\mathrm{f}(\%)$ \\
\hline Bilimsel Olarak Kabul & - & - & 7 & $\% 29.17$ \\
\hline Edilebilir Cevaplar KISMİ DOĞRU & - & - & 6 & $\% 25.00$ \\
\hline Bilimsel Olarak Kabul Edilemez Cevaplar & 20 & $\% 83.34$ & 11 & $\% 45.83$ \\
\hline Kodlanamaz & 1 & $\% 4.16$ & - & - \\
\hline Cevap Yok & 3 & $\% 12.50$ & - & - \\
\hline
\end{tabular}

Tablo 7. Yedinci soruya ait öğrenci yanıtlarının dağılımı

\begin{tabular}{|c|c|c|c|c|}
\hline \multirow{2}{*}{ Cevap Kategorileri } & \multicolumn{2}{|c|}{ Öğretim öncesi } & \multicolumn{2}{|c|}{ Öğretim sonrası } \\
\hline & $\mathrm{n}$ & $\mathrm{f}(\%)$ & $\mathrm{n}$ & $\mathrm{f}(\%)$ \\
\hline Bilimsel Olarak Kabul & - & - & 6 & $\% 25.00$ \\
\hline KISMİ DOĞRU & - & - & 9 & $\% 37.50$ \\
\hline Bilimsel Olarak Kabul Edilemez Cevaplar & 21 & $\% 87.50$ & 8 & $\% 33.34$ \\
\hline Kodlanamaz & - & - & - & - \\
\hline Cevap Yok & 3 & $\% 12.50$ & 1 & $\% 4.16$ \\
\hline
\end{tabular}

Yedinci soruda, öğrencilere Şekil 2'deki gibi Güneş, Dünya ve Ay'ın konumları verilerek Ay'ın hangi evrede olabileceği sorulmuştur. Cevaplar incelendiğinde; son dördün çizip açıklayanlar tam doğru cevaplarda, son dördün diyen fakat açıklama yapmayanlar kısmi doğru cevaplarda, ilk dördün cevabı bilimsel olarak kabul edilemez cevaplarda, cevap vermeyenler cevap yokta yer almaktadır. Yedinci sorunun analizinden elde edilen bulgular Tablo 7'de yer almaktadır.

Tablo 7 incelendiğinde; bilimsel olarak kabul edilebilir cevaplarda öğretim öncesinde kimsenin bulunmadığı fakat öğretim sonrasında öğrencilerin verdiği cevapların \%62.50'inin bu cevap kategorisinde yer aldığı gözlemlenmektedir.
Bilimsel olarak kabul edilemez cevapların \%87.50’ten \%33.34'e gerilediği tespit edilmiştir.
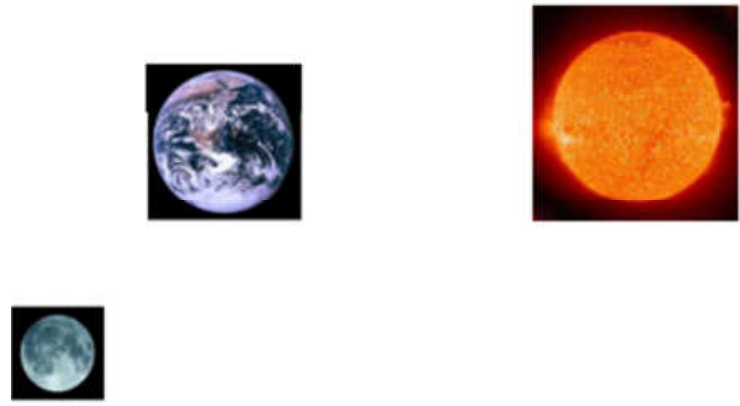

Şekil 2. Yedinci soruya ait Dünya, Güneş ve Ay’ın konumları 
Kodlanamaz cevap kategorisinde öğretim öncesi ve sonrasında öğrenci cevabı bulunmamaktadır. Cevap yok kategorisinde ise ögrretim öncesi sınıfın $\% 12.50$ 'ini oluştururken, öğretim sonrasında bu say1 \% 4.16'ya düşmektedir.

\section{Sonuç ve tartışma}

$\mathrm{Bu}$ çalışma bulgular sonucunda ulaşılan sonuçlara aşağıda yer verilmektedir;

1. Soruda; bilimsel olarak kabul edilebilir yanıtlardaki anlamlı artış öğretimin etkililiğini ön plana çıkarmaktadır. Yani; öğrencilerin Ay'ın evrelerinin oluşum sebepleri sorusunda bilimsel cevap vermelerinde artış gözlemlenmiştir.

2. Soruda; kodlanamaz cevaplardaki azalma olmasında rağmen beklenenden az olması öğrencilere Ay’ın hareketleri denildiğinde Ay'ın evreleri olarak algilanmasindan kaynaklanmaktadır. Öğretim etkili olmasına rağmen öğrencilerin soruyu yanlış anlamasından kaynaklı sonuç ortaya çıkmaktadır.

3. Soruda; Ay'ın evrelerinin oluşum sırası denildiğinde öğrencilerin çizimlerdeki hataları son testte de devam etmektedir. Buradan öğrencilerin görsel zekayı kullanmalarında zorlandığı düşünülebilir.

4. Soruda; öğrencilerin Dolunay evresinin oluşumunu çizmelerinde son testteki artış öğretimin bu soruda anlamlı bir katkısı olduğu tespit edilmiştir.

5. Soruda; öğretim sonucunda son testte elde edilen bulgular sonucunda öğrencilerin Yeniay evresinin oluşumunun çizilmesinde etkili olduğu tespit edilmiştir.

6. Soruda; öğrencilerin öğretim sonucunda doğru cevaba yöneldikleri tespit edilmiştir. Buradan öğrencilerde bilimsel cevap vermelerinde artış olduğu söylenebilmektedir.

7. Soruda; bir önceki soru gibi öğretim sonucunda öğrencilerin doğru cevaba yöneldikleri tespit edilmiştir. Böylece öğretimin etkililiği ön plana çıkmaktadır.

Genel olarak sonuçlar incelendiğinde öğrencilerin yanlış anlamasından kaynaklı sorular dışında öğretim sonucunda öğrencilerin; sorulara bilimsel cevap vermelerinde ve sorgulama becerilerinde artış olduğu gözlemlenmiştir. Ay'ın evreleri ile ilgili bir çalışmanın sonucunda işbirlikli öğrenme yönteminin ögrrencilerin bilimsel kavram düzeyine geçmelerinde daha etkili olduğunu belirlenmiştir [15]. Diğer çalışmalar incelendiğinde sorgulamaya dayalı öğretimin öğrencilerin bilimi öğrenmelerinde etkili olduğu [5] ayrıca sorgulama becerilerini geliştirdiği [7] sonucuna varılmaktadır. Sorgulamaya dayalı öğretimin öğretmen adaylarında feni öğrenmede olumlu tutum geliştirdiği [6] sonucu ortaya çıkmaktaıdr. Bunun gibi Ay’ın evreleri ile ilgili öğrencilerin fikirlerini araştıran çalışmaların sonucunda öğrencilerin fikirlerinde gelişim olduğu gözlemlenmektedir. Yapılan çalışmamızda da öğrencilerin öğretim sonrasında bilimsel cevap vermelerinde artış olduğu gözlemlenmektedir.

$\mathrm{Bu}$ çalışmada sorgulamaya dayalı öğretimin ortaokul 6.sınıf “Ay'ın Evreleri” konusunda öğrencilerin kavramsal anlamalarına etkisinin araştırılması amaçlanmıştır. $\mathrm{Bu}$ çalışmanın sonucunda bilimsel olarak kabul edilemez cevap kategorisinde yer alan cevaplar yerini bilimsel olarak kabul edilebilir cevap kategorisindeki kısmi doğru ve tam doğru kategorilerinde yer alan cevaplara bıraktığı tespit edilmiştir. Buradan sorgulama temelli öğretimin anlamlılığı göz önüne çıkmaktadır. Öğretim sonrasında kullanılan etkinliklerin faydalı olduğu gözlemlenmiştir.

\section{4. Öneriler}

Bu çalışma 1şığında Ay’n evreleri ve araştırma sorgulamaya dayalı öğretim ile ilgili çalışma yapmak isteyen araştırmacılara önerilerimiz,

- Öğrencilerin öğrenme sürecinde daha aktif sorumluluk aldıkları ve kendilerini birer bilim adamı gibi hissettikleri bilimsel süreç becerilerini içeren etkinliklerinde içinde olduğu sorgulamaya dayalı ders planının ön planda olduğu dersler işlenebilir.

- Çalışmalarda birçok öğretim modeli kullanılmaktadır. Araştırmamızda öğrenme halkası modeli kullanılmıştır. $\mathrm{Bu}$ çalışmadan farklı olarak $5 \mathrm{E}$ veya $7 \mathrm{E}$ öğretim modeline göre tasarlanan öğretim gerçekleştirilebilir.

- Kitaplardaki etkinlikler haricinde fen derslerinde konu kazanımlarına ve sorgulama ögretim modeline uygun etkinlikler geliştirebilir.

- Çalışma grubu genişletilerek daha çok öğrencinin de olduğu kapsamlı bir çalışma yapılabilir.

- Gelecek araştırmalarda sorgulamaya dayalı etkinliklerin haricinde tutum ölçeği gibi veri toplama araçları kullanılarak araştırma konusu genişletilebilir. 


\section{Kaynakça}

[1] MEB, İlköğretim kurumları (ilkokullar ve ortaokullar) fen bilimleri dersi $(3,4,5,6,7$ ve 8. sinıflar) öğretim programı. Ankara (2013).

[2] Tatar, N. and Kuru, M., Fen eğitiminde araştırmaya dayalı öğrenme yaklaşımının akademik başarıya etkisi. Hacettepe Üniversitesi Eğitim Fakültesi Dergisi, 31, 147-158 (2006).

[3] Novak, A., Scientific Inquiry. Bioscience, 14, 25-28 (1964).

[4] National Research Council (NRC) National Science Educational Standards. Washington, D.C.: National Academy Press (1996).

[5] Yurt, Ö. and Ömeroğlu, E., araştırmaya dayalı bilim eğitim programı'nın 60-72 aylık çocukların bilim öğrenmelerine etkisi. Bayburt Eğitim Fakülttesi Dergisi, 8, 1, 135-145 (2016).

[6] Kaya, S., Sınıf öğretmeni adaylarının fen öğretimi öz-yeterlilik inançlarının fen öğretimi dersine bağlı olarak değişimi. Mustafa Kemal Ü̉niversitesi Sosyal Bilimler Enstitüsü Dergisi, 10, 21, 55-69 (2013).

[7] Duran, M., Araştırmaya dayalı öğrenme yaklaşımına dayalı etkinliklerin öğrencilerin sorgulayıcı öğrenme becerileri üzerine etkisi. International Journal of Social Science, 32, 399-420 (2015).

[8] Keçeci, G. and Kırbağ Zengin, F., Araştırma ve sorgulamaya dayalı fen öğretiminin öğrencilerin bilimsel süreç becerilerine ve tutumlarına etkisi. International Journal of Social Science, 47, 269-287 (2016).

[9] Açışlı, S., Turgut, Ü., Altun Yalçın, S. and Gürbüz, F., Elektrik konusunda 5E öğrenme modeline dayalı öğretimin üniversite öğrencilerinin bilimsel işlem becerilerine ve fizik laboratuvarına karşı tutumlarına etkisi. Bayburt Üniversitesi Eğitim Fakültesi Dergisi, 4, 2, 80-92 (2009).

[10] Şenel Çoruhlu, T. and Çepni, S., Zeniginleştirilmiş 5E modelinin öğrenci kavramsal değişimi üzerine etkisi: Astronomi örneği. Kastamonu Eğitim Dergisi, 24, 4, 1785-1802 (2016).

[11] Aksoy, G. and Gürbüz, F., An example for the effect of $5 \mathrm{E}$ model on the academic achievement of students in the unit of force and motion. İnönü Üniversitesi Eğitim Fakültesi Dergisi, 14, 2, 1-16 (2013).

[12] Yurdatapan, M. and Gülhan, F., 5E Modeline uygun araştırma sorgulamaya dayalı etkinliklerin 5.sınıf öğrencilerinin çevre ile ilgili tutum ve davranışlarına etkisi. Mustafa Kemal Üniversitesi Sosyal Bilimler Enstitüsü Dergisi, 11, 27, 237-258 (2014).

[13] Demirezen, S. and Yağbasan, R., 7E Modelinin basit elektrik devreleri konusundaki kavram yanılgıları üzerine etkisi. Hacettepe Üniversitesi Eğitim Fakültesi Dergisi, 28, 2, 132-151 (2013).

[14] Ezberci, E., Üstkavramsal faaliyetleri aktif hale getirici etkinliklerle desteklenmiş $5 \mathrm{E}$ öğrenme döngüsü modelinin 7.sınıf öğrencilerinin ay'ın evreleri konusundaki kavramsal anlamalarına etkisi. Yüksek Lisans Tezi. Gazi Üniversitesi (2014).

[15] Öztürk, D., İlköğretim 6. ve 8. sinıf öğrencilerinin ay'ın evreleri konusunda kavram yanılgıları ve kavram değişimlerinin işbirliğine dayalı ortamda incelenmesi. Yüksek Lisans Tezi. Çukurova Üniversitesi. Adana. Türkiye (2011).

[16] Kurnaz, M.A. and Değirmenci, A., Mental models of 7th grade students on Sun, Earth and Moon. Elemantary Education Online, 11, 1, 137-150 (2012).

[17] Öztürk, A. and Doğanay, A., İlköğretim beşinci ve sekizinci sınıf öğrencilerinin dünyanın şekli ve yerçekimi kavramlarına ilişkin anlamaları ve zihinsel modelleri. Kuram ve Uygulamada Eğitim Bilimleri, 13, 4, 2455-2476, (2013).

[18] Küçüközer, H., The effects of 3D computer modelling on conceptual change about seasons and phases of the Moon. Physics Education, 43, 6, 632-636, (2008).

[19] Küçüközer, H., Designing a powerful learning environment to promote durable conceptual change, Computers \& Education, 68, 482-494, (2013).

[20] Küçüközer, H. and Bostan, A., Ideas of kindergarten students on the day-night cycles, the seasons and the Moon phases. Journal of Theory and Practice in Education, 6(2), 267-280, (2010).

[21] Büyüköztürk, Ş., Çakmak, E.K., Akgün, Ö.E., Karadeniz, Ş. and Demirel, F., Bilimsel Araştırma Yöntemleri. Ankara: Pegem Akademi, 177-184, (2008). 